\title{
RADIO PROTECTIVE EFFECTS OF GINSENG EXTRACT IN GAMMA-RAYS INDUCED CHROMOSOMAL DAMAGES OF HUMAN LYMPHOCYTE
}

\author{
M. Syaifudin ${ }^{1}$, Jie-Young Song ${ }^{2}$, Yun-Sil Lee ${ }^{3}$, and Chang-Mo Kang ${ }^{4}$ \\ ${ }^{1 .}$ Center For Technology of Radiation Safety and Metrology \\ National Nuclear Energy Agency (BATAN), Jakarta, Indonesia. \\ 2. Laboratory of Radiation Immunology, Korea Institute of Radiological and Medical Sciences \\ (KIRAMS), Seoul, Republic of Korea. \\ 3. Laboratory of Radiation Effects, KIRAMS, Seoul, Republic of Korea. \\ ${ }^{4 .}$ Laboratory of Radiation Cytogenetics and Epidemiology KIRAMS, Seoul, Republic of Korea.
}

\begin{abstract}
RADIOPROTECTIVE EFFECTS OF GINSENG EXTRACT IN GAMMARAYS INDUCED CHROMOSOMAL DAMAGES OF HUMAN LYMPHOCYTE. Ginsan, a polysaccharide extracted from Panax ginseng and subsequently referred as ginseng, posses various biological properties as an anticancer and antioxidant agent. Ginseng also approved effective against radiation effects through its immunomodulating actions in whole body irradiated mouse. But its protective effects on radiation induced DNA damage are not thoroughly investigated, mainly in human. This experiment aimed to assess the effects of ginseng at 2 working doses in suppressing radiation effects of human peripheral blood lymphocyte (PBL) i.e. chromosome aberration and micronuclei yields. The treatment times were 24 hours before, subsequently ( 0 hour) or 3 hours after and irradiation with gamma rays at doses of $0.5-2.0 \mathrm{~Gy}$ (dose rate of $3.16 \mathrm{~Gy} / \mathrm{min}$ ). Treated and untreated blood cultivation and metaphase spreading technique was done according to standard procedures. Results showed that without ginseng treatments, radiation significantly increased dicentrics and micronuclei frequencies. Different with the results in mouse study, however, our results indicated that none of the experimental concentrations of ginseng crude water extract tested had an effect on baseline chromosomal aberration and micronuclei (MN) yields in PBL. A protective effect was only seen in chromosome aberration yields of sample irradiated with 2.0 Gy and treated with ginseng $3 \mathrm{~h}$ post irradiation rather than $24 \mathrm{~h}$ pre-irradiation in one volunteer. Opposite results that ginseng suspected to be a weak radiosensitizer was found in some cases. This may be due to discrepancies exist in route of treatment and its fundamental mechanisms of protective action between both studies. Even though in general it was not effective, the possible mechanism involved in radioprotective influence of ginseng is discussed.
\end{abstract}

Key words : Radio protective Effect, Ginseng Extract, Gamma-Rays, Human Lymphocyte

\section{INTRODUCTION}

Ginseng that has been used as a medicine for at least 2,000 years, currently is being cultivated throughout the world [1]. Numerous biochemical and pharmacological studies reveal that ginseng possess various biological properties as an anticancer, antioxidant, anti-inflammatory, antibiotic, anti-fungal and anti-hepatotoxic agent. Anticancer and therapeutics were potent of its active components such as ginsenosides in saponins of the 
ginseng root, while polysaccharides have been observed to have immunomodulating and antiproliferative effects in certain tumor cell lines [2-6].

In more detail studies ginseng was known to increase the rate of production of serum albumin and gamma globulin as well as DNA and RNA protein, and lipid synthesis in bone marrow cells. In radiation therapy adjunct, several studies reported that water-extracted polysaccharides of ginseng injection into mice with $100 \mathrm{mg} / \mathrm{kg}$ before exposure to ionizing radiation could survived at given radiation dose $45 \%$ more intense than control. This is due to cytokines that are required for hematopoietic recovery was induced with enhanced T-helper 1 function. Moreover, the pretreated cells had a significantly increased number of bone marrow, spleen cells, granulocyte-macrophage colony-forming cells, and circulating neutrophils $[4,7]$. The antioxidant activities of ginseng also help explain its DNA-preserving qualities with respect to some carcinogens and inflammation. Ginseng extracts have been shown to scavenge reactive oxidative species, a typical product induced by ionizing radiation [8-10].

Zhang et al [11] have revealed that the water-soluble extract of whole ginseng injected intraperitoneally $24 \mathrm{~h}$ before irradiated gave the best protection against gamma radiation in mice in term of LD50/30. Treatment with ginseng for $24 \mathrm{~h}$ before radiation exposure, resulted in a significant linear decline of MN yields as ginseng concentration increases. These results indicated that ginseng crude water extract exerts no apparent cytogenetic effect on human PBL at concentrations up to 2000 microgram/ML as evaluated by the CBMN assay and the protection of ginseng water extract against ${ }^{137} \mathrm{Cs}$-induced $\mathrm{MN}$ in human $\mathrm{PBL}$ is concentration-dependence. Therefore, their findings indicated that ginseng may have therapeutic value as a possible radioprotector for normal tissue during radiotherapy of cancer patients. Preliminary clinical observations suggest that following radiotherapy or chemotherapy, partially purified ginseng components may reduce therapeutic-related side effects and stimulate recovery of hematopoietic functions in cancer patients. It is well known that the $\mathrm{G}_{0}$ stage PBL are particularly suitable for quantifying the effects of radioprotective chemicals in modifying radiation response, however, information regarding the effect of ginseng on human PBL is still need to be elucidated [6].

Ionizing radiations induced chromosomal aberrations such as dicentrics, rings, translocations, etc. appear as a result of double strand breaks and misrepaired damage [12]. The analysis of dicentric in lymphocytes is considered the most-sensitive biological method to quantify exposure to radiation for doses $>0.1 \mathrm{~Gy}$, if an adequate number of metaphases are analysed [13]. Damage to chromosomes is also manifested as breaks and fragments, which appears as $\mathrm{MN}$ in the rapidly proliferating cells [14]. Micronuclei are produced during mitosis due to various mechanisms, i.e., acentric fragments, multicentric chromosomes, damaged kinetochores and 
spindle fiber defects and it can be detected in the cytoplasm besides the cell nucleus as small nucleus-like particles [15]. In additional, the formation of $\mathrm{MN}$ in cytokinesis-blocked PBL is one of the most sensitive biomarkers for assessing genotoxicity or radiation damage in situ $[16,17]$. The aim of the present study is to evaluate the possible properties of ginseng extract against radiation-induced chromosomal damage.

\section{EXPERIMENTAL METHODS}

\section{Plant Materials and Treatment Procedure}

In this experiment, ginseng was obtained from Laboratory of Radiation Immunology, KIRAMS, Seoul, Korea. As reported, ginseng (a polysaccharide) preparation was started by purification from the ethanol insoluble fraction of the aqueous Panax ginseng extract, as described previously $[19,20]$. Ginseng was dissolved in phosphate buffer saline (PBS, pH 7.4) and filtered through a 0.25 micrometer Millipore membrane (Millipore, USA). The concentration of ginseng used were 100 and $1000 \mu \mathrm{g} / \mathrm{ML}$ working doses.

\section{Blood Collection and Irradiation}

Peripheral blood samples were collected in sterile heparinised vacutainers (Becton Dickinson) from three healthy volunteers (all males) aged between 30 and 47 years old (mean 39.67 y). No medicines or drugs were taken by all volunteers for at least six months prior to sampling and free from any diseases for more than 12 months. The treatment time in this experiment was similar with others $[11,18,19]$ i.e. 24 hour before, immediately and 3 hours after irradiation. For $24 \mathrm{~h}$ treatment, blood was mixed with culture medium in conical tube and keep in incubator at $37^{\circ} \mathrm{C}$ for 24 hours. Two other blood samples from the same volunteer were irradiated with ionizing radiation doses and then mixed with culture medium, followed by treatment with ginseng immediately and 3 hours post exposure. All three treatments were irradiated at a dose rate of $3.16 \mathrm{~Gy} / \mathrm{min}$ in Gammacell 3000 Elam Nordion International machine located in KIRAMS. The doses of gamma rays irradiation were $0.5-2.0 \mathrm{~Gy}$.

\section{Culture Set up For Unstable Chromosomal Aberration}

The procedure of analysis was according to standard procedures given by IAEA [21] with slight modifications. Two milliliters of irradiated and ginseng treated and control bloods were cultured at $37^{\circ} \mathrm{C}$ for $48 \mathrm{~h}$ in a humidified atmosphere containing $5 \% \mathrm{CO}_{2}$. The culture medium consisted of 8.0 ML of RPMI-1640 supplemented with $10 \%$ heat inactivated feotal calf serum and $1 \%$ streptomycin/penicillin. All the components of the culture 
medium were obtained from Gibco. Besides this, 3.0\% ML of phytohemagglutinin (PHA-Gibco BRL, Grand Island, NY) was added to stimulate cell division. After cultured for 48 hours, the contents of the tube were then centrifuged for ten minutes at $1500 \mathrm{rpm}$ and re-suspend in $8 \mathrm{ML}$ of $75 \mathrm{mM} \mathrm{KCl}$ (pre-warmed to $37^{\circ} \mathrm{C}$ ) for twenty minutes. At this stage, $2 \mathrm{ML}$ of $-20^{\circ} \mathrm{C}$ fresh fixative solution $(3: 1=$ methanol : acetic acid glacial) was added into the tube, and this fixation step was repeated four times (until white sediment was obtained).

\section{Scoring the Metaphases and Imaging}

Two slides were prepared for each sample, encoded, stained with $10 \%$ Giemsa (Merck) and mounted. The number of aberrations was observed under an Nikon microscope, using the 100x oil immersion objective, and a cell was considered as aberrant if it had one or more unstable CA (dicentric, rings and chromosome fragments) in complete metaphases with 46 centromers or more only as per the scoring criteria described in IAEA [21]. At least 500 first division metaphase cells were scored per sample. In the control samples 1000-2000 metaphase cells were analysed per donor. Tricentrics and tetracentrics were considered as one and two dicentric equivalents, respectively. Light microscopy was coupled to an image analysis system using a CCD (Char Coupled Device) camera (Model DP70, Olympus) to facilitate scoring and imaging. Digitized data were stored into a personal computer and processed using Adobe Photoshop.

\section{Culture Set up For Micronucleus Assay}

One and half milliliter of whole blood of the same volunteers was put into cultures containing 8.5 ML of RPMI 1640 medium with L-glutamine and $25 \mathrm{mM}$ HEPES buffer (Gibco Laboratories) supplemented with 10\% fetal calf serum (Gibco) and antibiotics. Purified phytohaemagglutinin (PHA P, $30 \mu \mathrm{g} / \mathrm{ML}$; Sigma Chemical Co., St Louis, MO) was added as mitogen. Cytochalasin B (6 $\mu \mathrm{g} / \mathrm{ML}$, stock solution $2 \mathrm{mg} / \mathrm{ML}$ in dimethylsulphoxide; Sigma Chemical Co.) was added $43 \mathrm{~h}$ after culture initiation to block cytokinesis. After an incubation period of $72 \mathrm{~h}$ the cells were collected, treated with a hypotonic solution of $0.075 \mathrm{M} \mathrm{KCl}$ (cooled at $4^{\circ} \mathrm{C}$ ) and prefixed with $2 \mathrm{ML}$ of cold pre-fixative solution (3\% formaldehyde in fresh fixative solution). Fixative was done with a mixture of methanol/glacial acetic acid as described [21,22]. After fixation the cells were dropped onto clean slides and allowed to dry. After mounted, MN was scored according to IAEA [21].

\section{Scoring Micronuclei (MN)}

Scoring of MN was conducted under a Nikon microscope with $100 \mathrm{x}$ magnification. The MN frequencies were scored according to the criteria 
proposed by IAEA [21] and Fenech, M. [23] : the diameter of an MN is less than one third of the diameter of the macronucleus, it is non-refractile and is not linked to the macronucleus by a nucleoplasmic bridge. MN partly overlapping with the nucleus or with each other were also taken into account. One thousand binucleated $(\mathrm{BN})$ cells were scored on one or two slides per individual. Imaging was done as chromosomal aberration.

\section{RESULTS AND DISCUSSION}

The frequencies of chromosomal aberrations (dicentrics and rings) for different doses of gamma irradiation in control and ginseng treated cultured human blood lymphocytes $(24 \mathrm{~h}$ before-, immediately after- and $3 \mathrm{~h}$ after-irradiation) were presented in Table 1. Whereas the results of experiment for micronuclei yield in the same lymphocyte cells were presented in Table 2. An increase in the frequencies of dicentrics and rings were observed in a dose dependent manner. Maximum number of dicentric (as high as 362 in 1000 cells counted) was observed at highest dose (2.0 Gy). Results showed that without ginseng treatments, radiation significantly increased dicentrics and micronuclei frequencies. Different with the results in mouse study, however, our results indicated that none of the experimental concentrations of ginseng crude water extract tested had an effect on baseline chromosomal aberration yields in PBL. A protective effect was only seen in chromosome aberration yields of sample irradiated with 2.0 Gy and treated with ginseng $3 \mathrm{~h}$ post irradiation rather than $24 \mathrm{~h}$ pre-irradiation. Opposite results showed that ginseng tended to be a radiosensitizer was found in some cases. This may be due to discrepancies exist in route of treatment and its fundamental mechanisms of protective action between both studies.

All concentration of ginseng assessed $(100$ and $1000 \mu \mathrm{g} / \mathrm{ml})$ was not clearly decreased the dicentric frequencies when the lymphocytes were exposed to $1 \mathrm{~Gy}$, moreover to $2.0 \mathrm{~Gy}$. At $2.0 \mathrm{~Gy}$ irradiation, $100 \mu \mathrm{g} / \mathrm{ML}$ of ginseng did not brought the dicentric frequencies still in normal level (Figure 1). Only $100 \mu \mathrm{g} / \mathrm{ML}$ of ginseng brought down the dicentric frequency to near normal level when the lymphocytes were irradiated at 2.0 Gy irradiation and this only found in one sample. Even $1000 \mu \mathrm{g} / \mathrm{ML}$ of ginseng pretreatment exhibited no any decreased levels of chromosome aberration in gamma-irradiated lymphocytes for all doses of irradiation. Ginseng pretreated $(100 \mu \mathrm{g} / \mathrm{ML})$ lymphocytes $(24 \mathrm{~h}$ pre-treated) showed slightly decreased frequencies of dicentric+rings when compared with gamma-irradiated cells only. Our very simple study also shows that gamma-irradiation caused a significant decrease in the levels of CA when compared with the normal lymphocytes. Ginseng pretreated groups did not showed any differences in dicentric yields when compared with corresponding gamma-irradiative groups. Further, ginseng pretreatment 
did not decreased frequencies of these radiation induced chromosomal alterations.

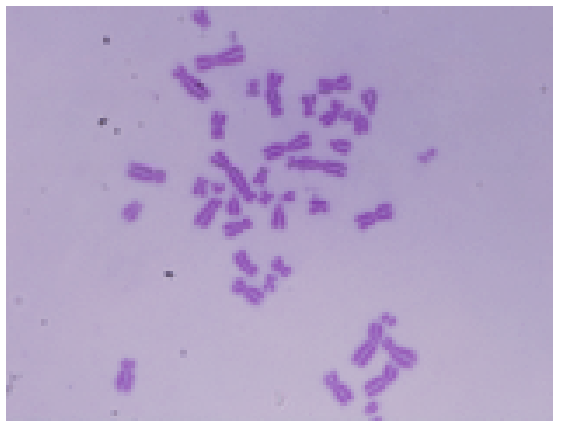

Figure 1. Three dicentric chromosomes induced by gamma rays with dose of $2.0 \mathrm{~Gy}$ and ginseng treatment $24 \mathrm{~h}$ before irradiation.

Table 1. Frequencies of chromosome aberrations induced by exposure to 0.1-2.0 Gy of gamma rays in blood sample treated with ginseng 24 pre-, $0 \mathrm{~h}$ post- and $3 \mathrm{~h}$ post-irradiation.

\begin{tabular}{|c|c|c|c|c|c|c|}
\hline $\begin{array}{c}\text { Volunteer } \\
\text { no. } \\
\text { (sex, age) }\end{array}$ & $\begin{array}{l}\text { Time of } \\
\text { ginseng } \\
\text { treatment }\end{array}$ & $\begin{array}{c}\text { Ginseng } \\
\text { Dose } \\
(\mu \mathrm{g} / \mathrm{ML})\end{array}$ & $\begin{array}{l}\text { Radiation } \\
\text { dose (Gy) }\end{array}$ & $\begin{array}{c}\text { Total cells } \\
\text { counted }\end{array}$ & $\begin{array}{c}\text { No. cell with } \\
\text { dicentric \& } \\
\text { rings }\end{array}$ & $\begin{array}{c}\text { Frequency of } \\
\text { dicentric \& rings }\end{array}$ \\
\hline 1 & - & 0 & 0.0 & 800 & 1 & 0.0013 \\
\hline \multirow{7}{*}{$\mathrm{M}, 42 \mathrm{y}$} & $0 \mathrm{~h}$ post & 100 & 0.0 & 500 & 3 & 0.0040 \\
\hline & & 0 & 0.1 & 650 & 12 & 0.0185 \\
\hline & $0 \mathrm{~h}$ post & 100 & 0.1 & 500 & 11 & 0.0220 \\
\hline & - & 0 & 0.5 & 800 & 48 & 0.0600 \\
\hline & $0 \mathrm{~h}$ post & 100 & 0.5 & 500 & 38 & 0.0760 \\
\hline & - & 0 & 1.0 & 500 & 74 & 0.1480 \\
\hline & $0 \mathrm{~h}$ post & 100 & 1.0 & 500 & 65 & 0.1300 \\
\hline 2 & $24 \mathrm{~h}$ pre & 100 & 0.0 & 800 & 3 & 0.0038 \\
\hline \multirow[t]{5}{*}{$\mathrm{M}, 30 \mathrm{y}$} & $24 \mathrm{~h}$ pre & 100 & 0.5 & 500 & 27 & 0.0540 \\
\hline & $24 \mathrm{~h}$ pre & 100 & 1.0 & 500 & 79 & 0.1580 \\
\hline & $3 \mathrm{~h}$ post & 100 & 0.0 & 800 & 2 & 0.0025 \\
\hline & $3 \mathrm{~h}$ post & 100 & 0.5 & 500 & 26 & 0.0520 \\
\hline & $3 \mathrm{~h}$ post & 100 & 1.0 & 500 & 74 & 0.1480 \\
\hline 3 & - & 0 & 0.0 & 2000 & 2 & 0.0010 \\
\hline \multirow[t]{8}{*}{ M, $42 \mathrm{y}$} & - & 0 & 1.0 & 2000 & 114 & 0.0570 \\
\hline & - & 0 & 2.0 & 1500 & 362 & 0.2413 \\
\hline & $24 \mathrm{~h}$ pre & 100 & 0.0 & 800 & 3 & 0.0038 \\
\hline & $24 \mathrm{~h}$ pre & 100 & 1.0 & 500 & 116 & 0.2320 \\
\hline & $24 \mathrm{~h}$ pre & 100 & 2.0 & 500 & 246 & 0.4920 \\
\hline & $3 \mathrm{~h}$ post & 100 & 0.0 & 800 & 1 & 0.0013 \\
\hline & $3 \mathrm{~h}$ post & 100 & 1.0 & 500 & 70 & 0.1400 \\
\hline & $3 \mathrm{~h}$ post & 100 & 2.0 & 500 & 202 & 0.4040 \\
\hline 4 & $0 \mathrm{~h}$ post & 0 & 0.0 & 500 & 1 & 0.0020 \\
\hline \multirow[t]{8}{*}{ M, $47 \mathrm{y}$} & $0 \mathrm{~h}$ post & 100 & 0.0 & 400 & 1 & 0.0025 \\
\hline & $0 \mathrm{~h}$ post & 1000 & 0.0 & 400 & 2 & 0.0050 \\
\hline & $0 \mathrm{~h}$ post & 0 & 0.5 & 500 & 10 & 0.0200 \\
\hline & $0 \mathrm{~h}$ post & 100 & 0.5 & 400 & 7 & 0.0175 \\
\hline & $0 \mathrm{~h}$ post & 1000 & 0.5 & 400 & 8 & 0.0200 \\
\hline & $0 \mathrm{~h}$ post & 0 & 1.0 & 500 & 15 & 0.0300 \\
\hline & $0 \mathrm{~h}$ post & 100 & 1.0 & 400 & 19 & 0.0470 \\
\hline & $0 \mathrm{~h}$ post & 1000 & 1.0 & 400 & 12 & 0.0300 \\
\hline
\end{tabular}


Across the 1.0 - 2.0 Gy in vitro radiation dose range used in this study, the yields of $\mathrm{MN}$ in PBL without ginseng treatment were consistently higher for higher doses of radiation. We found that a $24 \mathrm{~h}$ pre-treated ginseng crude water extract appeared to have very weak radioprotective effects as evidenced by MN analysis (Table 2). However, in general the addition of ginseng at the concentrations used in this study could not clearly decreased the ${ }^{137} \mathrm{Cs}$-induced MN in PBL.

Table 2. Effects of ginseng treatment on MN yields in human irradiated and non-irradiated peripheral blood lymphocytes.

\begin{tabular}{|c|c|c|c|c|c|c|}
\hline $\begin{array}{c}\text { Volunteer } \\
\text { no. } \\
\text { (sex, age) }\end{array}$ & $\begin{array}{l}\text { Time of } \\
\text { ginseng } \\
\text { treatment }\end{array}$ & $\begin{array}{c}\text { Ginseng } \\
\text { Dose } \\
(\mu \mathrm{g} / \mathrm{ML})\end{array}$ & $\begin{array}{l}\text { Radiation } \\
\text { dose (Gy) }\end{array}$ & $\begin{array}{c}\text { Total cells } \\
\text { counted }\end{array}$ & $\begin{array}{c}\text { Total no. of } \\
\text { MN }\end{array}$ & $\begin{array}{c}\text { Frequency } \\
\text { (MN/cell } \\
\text { counted) }\end{array}$ \\
\hline 1 & $0 \mathrm{~h}$ post & 0 & 0.0 & 1000 & 3 & 0.003 \\
\hline \multirow{8}{*}{$\mathrm{M}, 47 \mathrm{y}$} & $0 \mathrm{~h}$ post & 100 & 0.0 & 1000 & 11 & 0.011 \\
\hline & $0 \mathrm{~h}$ post & 1000 & 0.0 & 1000 & 11 & 0.011 \\
\hline & $0 \mathrm{~h}$ post & 0 & 0.5 & 1000 & 35 & 0.035 \\
\hline & $0 \mathrm{~h}$ post & 100 & 0.5 & 1000 & 39 & 0.039 \\
\hline & $0 \mathrm{~h}$ post & 1000 & 0.5 & 1000 & 71 & 0.071 \\
\hline & $0 \mathrm{~h}$ post & 0 & 1.0 & 1000 & 107 & 0.107 \\
\hline & $0 \mathrm{~h}$ post & 100 & 1.0 & 1000 & 113 & 0.113 \\
\hline & $0 \mathrm{~h}$ post & 1000 & 1.0 & NA & NA & NA \\
\hline 2 & $0 \mathrm{~h}$ post & 0 & 0.0 & 1000 & 13 & 0.013 \\
\hline \multirow[t]{5}{*}{$\mathrm{M}, 42 \mathrm{y}$} & $0 \mathrm{~h}$ post & 100 & 0.0 & 1000 & 16 & 0.016 \\
\hline & $0 \mathrm{~h}$ post & 0 & 0.5 & 1000 & 53 & 0.053 \\
\hline & $0 \mathrm{~h}$ post & 100 & 0.5 & 1000 & 51 & 0.051 \\
\hline & $0 \mathrm{~h}$ post & 0 & 1.0 & 1000 & 111 & 0.111 \\
\hline & $0 \mathrm{~h}$ post & 100 & 1.0 & 1000 & 103 & 0.103 \\
\hline 3 & $3 \mathrm{~h}$ post & 1000 & 0.0 & 1000 & 12 & 0.012 \\
\hline \multirow[t]{5}{*}{$\mathrm{M}, 30 \mathrm{y}$} & $3 \mathrm{~h}$ post & 1000 & 0.5 & 1000 & 52 & 0.052 \\
\hline & $3 \mathrm{~h}$ post & 1000 & 1.0 & 1000 & 97 & 0.097 \\
\hline & $24 \mathrm{~h}$ pre & 1000 & 0.0 & 1000 & 14 & 0.014 \\
\hline & $24 \mathrm{~h}$ pre & 1000 & 0.5 & 1000 & 66 & 0.066 \\
\hline & $24 \mathrm{~h}$ pre & 1000 & 1.0 & 1000 & 98 & 0.098 \\
\hline 4 & $3 \mathrm{~h}$ post & 1000 & 0.0 & 1000 & 17 & 0.017 \\
\hline \multirow[t]{5}{*}{ M, 42 y } & $3 \mathrm{~h}$ post & 1000 & 1.0 & 1000 & 90 & 0.090 \\
\hline & $3 \mathrm{~h}$ post & 1000 & 2.0 & 1000 & 200 & 0.200 \\
\hline & $24 \mathrm{~h}$ pre & 1000 & 0.0 & 1000 & 10 & 0.010 \\
\hline & $24 \mathrm{~h}$ pre & 1000 & 1.0 & 1000 & 111 & 0.111 \\
\hline & $24 \mathrm{~h}$ pre & 1000 & 2.0 & 1000 & 228 & 0.228 \\
\hline
\end{tabular}

Different with study on mice, this study could not revealed a radioprotective effect of ginseng. In assessing the effect of ginseng extract in modifying the radiation-induced $M N$ yield in human $G_{0}$ PBL with cytokinesis-blocked (CB) assay, we found that at 0 Gy and without the presence of ginseng extract, MN yield was 11.9 per 1000 binucleated (BN) cells (Figure 2). Different concentrations of ginseng crude water extract treatment did not affect the MN yields. After 0.5 and $1.0 \mathrm{~Gy}$ exposures, radiation alone increased the $\mathrm{MN}$ yields, respectively, to 44.0 and 109.0 per $1000 \mathrm{BN}$ cells. However, treatment with ginseng for $24 \mathrm{~h}$ before, 
immediately after or 3 hour after radiation exposure, resulted in no reduction in $\mathrm{MN}$ yields for all ginseng concentrations tested.

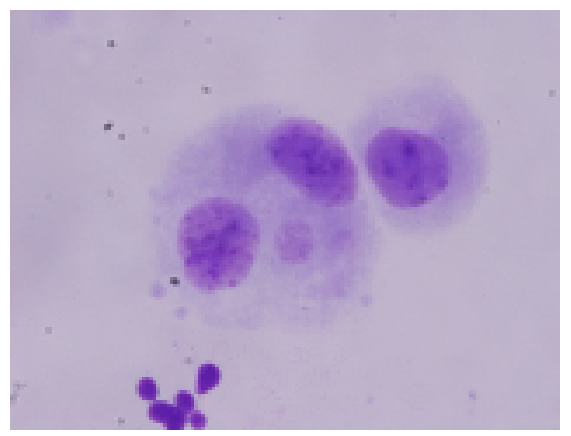

Figure 2. Micronuclei (small round shape besides binucleated cells in cytoplasm) induced by 0.5 Gy of gamma rays and treated with ginseng of $100 \mu \mathrm{g} / \mathrm{ML} 3$ hour post irradiation.

These results indicated that ginseng crude water extract exerts no apparent cytogenetic effect on human PBL at all concentrations assessed as evaluated by the CBMN assay; and the protection of ginseng water extract against ${ }^{137} \mathrm{Cs}$-induced $\mathrm{MN}$ in human PBL is not known. Therefore, our findings could not clearly indicate that ginseng may have therapeutic value as a possible radioprotector for normal tissue during radiotherapy of cancer patients. Based on the limited quantitative information in the literature, this simple research addresses the issue of the radioprotective effects of ginseng on mammalian cells obtained from three human peripheral blood lymphocytes. The significant radioprotective effects of different ginseng preparations were not demonstrated in vitro by cytokinesis-blocked micronuclei assay. Results of research did not clearly indicate that the water-soluble extract of whole ginseng appears to give a protection against radiation - induced damage. However, although the exact underlying radioptrotective mechanism of ginseng is unclear, it could be through its antioxidantative capability by scavenging free radicals responsible for DNA damage.

The role of plant extracts in ionizing radiation injury and its potential to reduce deleterious effects had been studied in animal models and human for more than 50 years [24]. Ginseng, one of more than ten thousands plant extracts analyzed its efficacy, are proven to be less effective radioprotectors in human in certain doses, as approved in this study, but may provide a longer window of protection against lethality and other effects of low dose, low-dose rate exposures. As many ginseng extracts had antimutagenic properties, it is need further examination with respect to long-term radiation (chronics) effects. In vivo studies in experimental animals have included 
protection against radiation-induced lethality due to hematopoietic or gastrointestinal injury, other specific tissue damage, apoptosis, mutagenesis, and carcinogenesis.

Since the 1980's, the radioprotective effects of Panax ginseng ( $P$. ginseng) and its partially purified constituents have been documented in experimental models $[3,18]$. Ben-Hur and Fulder [3] demonstrated that in the presence of partially purified $P$. ginseng saponin mixture, Chinese hamster V79 fibroblasts are significantly more resistant to subsequent $\gamma$-irradiation as determined by the ex vivo colony forming assay. In the studies of cultured spleen lymphocytes from mice, application of $P$. ginseng water extract $48 \mathrm{~h}$ before ${ }^{\gamma}$-ray-irradiation has been shown to reduce the frequency of DNA double strand breaks, and it also has been demonstrated to reduce the degree of radiation-induced apoptosis in both jejunal crypt cells and hair follicles [25]. In addition, Hsu et al. [26] found in ICR mice that the intraperitoneal injection of a Chinese herbal medicine that contains $25 \%$ of $P$. ginseng root before whole-body X-ray exposure (0-5 Gy) markedly enhanced the radiotolerance of bone marrow stem cells and peripheral hematocytes.

In contrast to the research in rodents, however, reports on the radioprotective effects of ginseng in human populations are very limited, although one clinical study from Korea suggests that partially purified $P$. ginseng components may reduce morbidities and stimulate the recovery of hematopoietic functions in cancer patients [27]. Moreover, since unrepaired or misrepaired DNA damage in PBL may be responsible for micronuclei (MN) formation, Lee et al [18] recently assessed the effect of $P$. ginseng dried root crude water extract on the radiation-induced $\mathrm{MN}$ formation in human $\mathrm{G}_{0}$ PBL ex vivo using the cytokinesis-blocked micronuclei assay and found that treatment with ginseng $24 \mathrm{~h}$ before ${ }^{137} \mathrm{Cs}$ exposure (2 Gy) resulted in a linear decline of $\mathrm{MN}$ yields as ginseng concentration increased). These findings suggest that the ginseng crude water extract may contain a potential radioprotective constituent with therapeutic value in dampening the damaging effects of ionizing radiation on normal tissues without exhibiting any negative effects on PBL. Obviously, experimental studies on the radioprotective potential of this important ginseng compound are critically needed.

Song et al [19] reported that ginseng polysaccharide isolated from ginseng had a mitogenic activity and was also found to significantly increase the number of bone marrow cells, spleen cells, granulocyte-macrophage colony-forming cells, and circulating neutrophils, lymphocytes and platelets in irradiated mice. Pretreatment with ginseng protected mice from the lethal effects of ionizing radiation more effectively than when it was given immediately after or at various times after irradiation. A significant increase in the $\mathrm{LD}_{50 / 30}$ of mice pretreated with ginseng was also observed. These findings indicate that ginseng may be a useful agent to reduce the time necessary for reconstituting hematopoietic cells after irradiation. 
It has long been known that ionizing radiation can interact directly with biological chromophores such as deoxyribonucleic acid (DNA) and in so doing, can damage those molecules. The use of ionizing radiation has become an integral part of modern medicine. It is used for diagnostic as well as therapeutic purposes. The therapeutic differentiation may be achieved with chemical radiation sensitizers or protectors. The development of radiation protectors is important not only to enhance the effectiveness of cancer treatment, but also for the study of the underlying mechanisms of radiation cytotoxicity [27]. A wide variety of compounds have been tested for radioprotective activity, including ginseng extract and many antioxidants $[28,29]$. Of all the compounds studied as potential radioprotective agents, unfortunately, available radioprotective substances possess unacceptable toxicity limiting its clinical usefulness and the precise mechanisms responsible for radiation-induced cell death remain uncertain. Therefore, it is necessary to develop protectors that will minimize toxicity while maintaining efficacy [30]. This was assessed in this very simple and preliminary experiment.

In our study, we found that ginseng did not renders protection against gamma-radiation induced DNA damage expressed as chromosomal aberration and micronuclei in human lymphocyte. This is different with recent studies which are demonstrate that ginseng exhibits protective activity against oxygen species in whole body irradiated mouse. The baseline of protecting action of plant extract is discussed in the following paragraphs. It seems that the strong free radical scavenging effects of $P$. ginseng have been extensively documented by many studies [8, 31, 32] where the radioprotective effect of $P$. ginseng has been closely linked to its antioxidative capability through both the chelating of transition metal ions and the scavenging of free radicals responsible for DNA damage [33]. Lipid peroxidation leads to altered lysosomal membrane permeability and results in the release of hydrolytic enzymes in response to radiation-induced damage in vivo: $P$. ginseng extract has been shown to inhibit lipid peroxidation through transition metal chelation and scavenging of hydroxyl and superoxide radicals [31]. Recently, most effects of ginseng have been attributed to its antioxidant action. Moreover, ginseng has been shown to be strongly radioprotective through its ability to stimulate hematopoietic stem cells (colony-forming unit spleen) and produce a battery of cytokines such IL-1, IL-6, IL-12 and TNF- $\alpha$. Its was also to be proven in study with mice that ginseng exerted its radioprotective effect through activation of antioxidant defense systems $[4,25]$. However, this was not seen in PBL cells irradiated in vitro with gamma rays as revealed by this study.

A large number of compounds natural and synthetic have been evaluated for the purpose of radioprotection [34]. The development of radiation protectors is important not only to enhance the effectiveness of cancer treatment, but also for the study of the underlying mechanisms of 
radiation cytotoxicity [35]. Hence search for an ideal radioprotector without side effects like hypotension, nausea, vomiting etc. and toxicity is a compelling urgency. These side effects limit its clinical usefulness. An ideal radioprotector also should be free from side effects, should be long acting, less expensive and capable of long term storage without change in action and constitution. Moreover, the most effective in vivo radioprotectors, however, like plant flavanoids and thiol compounds studied so far are effective when administered before irradiation, as they must be present in the system at the time of irradiation [35]. Hence they can be used only when the eventuality of the exposure is known and are not suitable against unplanned exposures, e.g. accidents, spillage, warfare and terrorist attack. Free radical scavenging may be a likely mechanism of action as the extract was found to possess significant hydroxyl radical scavenging activity.

This research focused on the effectivity of ginseng to attenuate the radiation effects expressed as chromosomal damages. Ginseng is typical Korean and Chinese plant and also cultivated in USA. In fact, Indonesia also has many types of plant such as Buah Merah, of which their extracts can be used as radioprotector. Buah merah or Red fruit (pandanous conoideus), an original traditional medicine of Papua Indonesia, was approved for healing for any degenerative diseases, such as cancer, tumor, hepatitis, lever disease, prostate, diabetes, gout, cholesterol, hypertension, stroke, and can be used for a healing of HIV [36,37]. Buah merah contains high concentration of active and important compounds such as beta-caroten, tocopherol, oleic acid, linoleic acid, and dekanoic. The research should be undertaken to check the in vivo and in vitro radioprotective property of the aqueous extract of Buah merah which remain unexplored for their effectiveness in suppressing radiation damages especially chromosomal aberration/instability either by using rodent as experimental animal or pheripheral blood of Indonesian people. Further investigations are necessary to identify the active component(s) responsible for protection and to study their mechanism of action. This plant is widely available in our country, it is worthwhile to conduct detailed studies in order to explore the full potential of this plant in human radiation protection. Other plants, temulawak or wild ginger (curcuma xanthorrhiza Roxb) and Brotowali (Tiospora rumpii boerl) is also has prospective availability for cancer treatment, hence for suppressing chromosomal instability.

\section{CONCLUSION}

Results of this simple experiment showed that without ginseng treatments, gamma radiation significantly increased dicentrics and micronuclei frequencies. None of the experimental concentrations of ginseng crude water extract tested had an effect on baseline chromosomal aberration and micronuclei yields in pheripheral blood lymphocytes. A protective effect 
was only seen in chromosome aberration yields of sample irradiated with 2.0 Gy and treated with ginseng $3 \mathrm{~h}$ post irradiation rather than $24 \mathrm{~h}$ pre-irradiation. Opposite results that ginseng suspected to be a radiosensitizer was found in some cases. This may be due to discrepancies exist in route of treatment and its fundamental mechanisms of protective action between both studies. Most effects of ginseng have been attributed to its antioxidant action and strongly radioprotective through its ability to stimulate hematopoietic stem cells.

\section{ACKNOWLEDGEMENTS}

The authors are greatly obliged to KIRAMS, Republic of Korea for providing all chemicals and instrumentations needed for this experiment. The valuable technical assistance of member staff of Laboratory of Radiation Cytogenetics and Epidemiology (KIRAMS) is gratefully acknowledged.

\section{REFERENCES}

1. KENNEDY, DO. and SCHOLEY, AB., Pharmacol. Biochem. Behav., 75, 687-700 (2003).

2. KITTS, D.D. and HU, C. Pub. Health Nut., 4, 473-485 (2000).

3. BEN-HUR, E. and FULDER, S., Am. J. Chin. Med., 14, 48-56 (1981).

4. SONG, J.Y., HAN, S.K., BAE, K.G., LIM, D.S., SON, S.J., JUNG, I.S., YI, S.Y. and YUN, Y.S., Radiat. Res., 159, 768-774 (2003).

5. CHANG, T.K.H., CHEN, J. and BENETTON, S.A., Drug Metabol. Dis., 30, 378-384 (2002).

6. LEE, T.K., JOHNKE, R.M., ALLISON R.R., O'BRIEN, K.F. and DOBBS, Jr, L.J., Mutagenesis, 20 (4), 237-243 (2005).

7. LEE, Y., JIN, Y., LIM, W. et al., J. Steroid Biochem Mol Biol, 84, 463-468 (2003).

8. ZHANG, D., YASUDA, T., YU, Y., et al., Free Radio. Biol. Med., 20, 145-150 (1996).

9. LIU, Z.Q., LUO, X.Y., SUN, Y.X., et al., Biochim. Biophys. Acta, 1572, 58-66 (2002).

10. LIU, Z.Q., LUO, X.Y., LIU, G.Z., et al., J. Agric. Food Chem., 51, 2555-2558 (2003).

11. ZHANG, J.S., SIGDESTAD, C.P., GEMMELL, M.A., GRDINA, D.J., Radiation Reserach, 112 (1) 156-63 (1987).

12. OLIVE, P.L., Radiation Research, 150, 42-51 (1988). 
13. MONTORO, A., ALMONACID, M., SERRANO, J., SAIZ, M., BARQUINERO, J.F., BARRIOS, L., VERDU, G., PEREZ, J. and VILLAESCUSA, J.I., Radiation Protection Dosimetry, 115 (1-4), 461-464 (2005).

14. HOFER, M., MAZUR, L., POSPISIL, M., WEITEROVA, L. and ZNOJIL, V., Radiation Research, 154, 217-221 (2000).

15. MULLER, WU., and STREFTER, C., Adv. Mutagen. Res., 5, 1-133 (1994).

16. FENECH, M., BONASSI, S., TURNER, J., LANDO, C., CEPPI, M., CHANG, WP., HOLLAND, N., KIRSCH-VOLDERS, M. et al., Mutation Research, 534, 45-64 (2003).

17. CATENA, C., CONTI, D., PARASACCHI, P., MARENO, P. and BORTOLATO, B., Int. J. Radiat. Biol., 70, 301-308 (1996).

18. LEE, T.K., ALLISON, R.R., O'BRIEN, KF., KHAZANIE, P.G., JOHNKE, R.M., BROWN, R., BLOCH, R.M., TATE, M.L., DOBBS, L.J., and KRAGEL, P.J., Mutation Research, 557, (1) 75-84 (2004).

19. SONG, J.Y., HAN, S.K., SON, E.H., PYO, S.N., YUN, Y.S. and YI, S.Y., Int. Immunopharmacol., 2, 857-865 (2002).

20. AHN, J.Y., CHOI, I.S., SHIM, J.Y., YUN, E.K., YUN, Y.S., JEONG, G.J. and SONG, J.Y., Eur. J. Immunol., 36, 37-45 (2006).

21. INTERNATIONAL ATOMIC ENERGY AGENCY, Cytogenetic Analysis for Radiation Dose Assessment A Manual, Technical Reports Series No. 405, Vienna, Austria, (2001).

22. VRAL, A., VERHAEGEN, F., THIERENS, H. and DE RIDDER, L., Mutagenesis, 9, 439-443 (1994).

23. FENECH, M., Mutat. Res., 285, 35-44 (1993).

24. WEISS, JF. and LANDAUER, MR., Annals of the New York Academy of Sciences, 899, 44-60 (2000).

25. HAN, Y.S., SON, S.J., AKHALAIA, M., PLATONOV, A., SON, H.J., LEE, K.H., YUN, Y.S. and SONG, J.Y., Modulation of RadiationInduced Disturbances of Antioxidant Defense Systems by Ginsan, Advance Access Publication, 4 October (2005).

26. HSU, M.J., LEE, S.S., LEE, S.T. and LIN, W.W., Ganoderma lucidum, Br. J. Pharmacol., 139, 289-298 (2003).

27. HAHN, S.M., KRISHNA, M.C., SAMUNI, A., DEGRAFF, W., CUSCELA, D.O., JOHNSTONE, P. and MITCHELLl, JB., Cancer Res., 54, 2006s-2010s (1994).

28. DURAKOVIC, Arh. Hig. Rada. Toksikol., 44, 331-354 (1993). 
29. PARK, Y.S., KIM Y.G., CHANG, J.C., and KIM, DY., J. Biochem. Mol. Biol., 26, 184-191 (1993).

30. WEISS, J.F., KUMAR, K.S., WALDEN, T.L., NETA, R., LANDAUR, M.R. and CLARK, E.P., Int. J. Radiat. Biol., 57, 709-718 (1990).

31. KITTS, D.D., WIJEWICKREME, A.N. and HU, C., Mol. Cell. Biochem., 203, 1-10 (2000).

32. KIM, Y.K., GUO, Q. and PACKER, L., Toxicology, 172, 149-156, (2002).

33. KIM, S.H., CHO, C.K., YOO, S.Y., KOH, K.H., YUN, H.G. and KIM, T.H., In Vivo, 7, 467-470 (1993).

34. NAIR, C.K.K., PARIDA, D.K. and NOMURA, T., Journal of Radiation Research, 42, 21-37 (2001).

35. HAHN, S.M., KRISHNA, M.C., SAMUNI, A., DEGRAFF, W., CUSCELA, D.O., JOHNSTONE, P. and MITCHELL, J.B., Cancer Research, 54, 2006-2010 (1994).

36. MUN'IM, A., ANDRAJATI, R., and SUSILOWATI, H., Majalah Ilmu Kefarmasian, 3 (3), 153-161 (2006).

37. ANONIM, Buah Merah, the multi advantageous natural medicine, (http://buahmerahextract.com/research-buah-merah.html). 